\title{
HUBUNGAN KEMUDAHAN AKSES PRODUK ROKOK ELEKTRIK DENGAN PERILAKU PENGGUNAAN ROKOK ELEKTRIK DI ERA NEW NORMAL PADA MAHASISWA KESEHATAN MASYARAKAT UMKT
}

\author{
THE CORRELATION OF EASY ACCESS ELECTRIC CIGARETTE PRODUCTS \\ WITH ELECTRIC CIGARETTE USE BEHAVIOR IN THE NEW NORMAL ERA OF \\ PUBLIC HEALTH STUDENTS IN UMKT
}

\author{
Syahrizal Bobby Anggara1, Panca Ruswana', Nuril Khofifah Turohmi ${ }^{3}$, Muhammad Fahri ${ }^{4}$, \\ Sri Sunarti $5^{*}$ \\ 1,2,3,4,5 Fakultas Kesehatan Masyarakat, Universitas Muhammadiyah Kalimantan Timur \\ Jl. Ir. H Juanda No. 15 Kota Samarinda, Kalmantan Timur, Indonesia \\ *Email : srisunarti@umkt.ac.id
}

\begin{abstract}
Ease of access has an important role in e-cigarette users. Due to the affordable price, there are special shops for vape or e-cigarettes that have been spread as well as online shops selling various types of ecigarettes, making it easy for users to use e-cigarettes. This research analyzed to correlation between the ease of access electric cigarette product factor and the behavior of using e-cigarettes in the new normal era in public health students UMKT. Methodology This research used a cross-sectional research design with the sample in this study being undergraduate students of public health UMKT with a sample of 231 students, and using stratified random sampling technique to determine the number of respondents. In this independent variable is the behavior of using e-cigarettes, and the dependent variable is the ease of access. For this research instrument using google form as a questionnaire instrument. The results this research between ease of access and the use of e-cigarettes in the new normal era for UMKT public health students.
\end{abstract}

Keywords: E-cigarettes; Ease of Access; the behavior of using e-cigarettes;Covid-19

\begin{abstract}
ABSTRAK
Kemudahan mengakses memiliki peranan penting dalam pengguna rokok elektrik. Karena harga yang tejangkau, terdapat toko khusus vape atau rokok elektrik yang sudah tersebar serta toko online yang menjual berbagai jenis rokok elektrik membuat pengguna mudah mengakses rokok elektrik.Penelitian ini untuk menganalisis adanya hubungan antara faktor kemudahan akses produk rokok elektrik dengan perilaku penggunaan rokok elektrik di era new normal pada mahasiswa kesehatan masyarakat UMKT. Metodologi Penelitian ini menggunakan desain penelitian cross sectional dengan sampel yang ada di penelitian ini adalah mahasiswa S1 kesehatan masyarakat UMKT dengan jumlah sampel 231 mahasiswa, serta menggunakan teknik stratified random sampling untuk menentukan jumlah responden. Pada variable indipenden ini adalah perilaku penggunaan rokok elektrik, dan variable dependen adalah kemudahan akses. Untuk instrument penelitian ini menggunakan google form sebagai instrument kuesioner. Hasil dalam penelitian ini, ada hubungan antara kemudahan akses dengan penggunaan rokok elektrik di era new normal pada mahasiswa kesehatan masyarakat UMKT.
\end{abstract}

Kata Kunci: Rokok elektrik; Kemudahan Akses; perilaku penggunaan rokok elektrik;Covid-19 


\section{PENDAHULUAN}

Setelah di tetapkan WHO bahwa pandemi COVID-19, untuk mengurangi dampak yang di akibatkan oleh pandemic covid-19 melalui pembatasan aktivitas di luar rumah mengharuskan sebagian besar pekerja melakukan pekerjaannya dari rumah atau work from fome (WFH) (1). Terjadi perubahan-perubahan kebiasaaan masyarakat yang di anggap normal mengalami perubahan sejak adanya Covid-19. Adanya perubahan kebiasaan normal yang biasa di lakukan masyarakat ini lah yang di sebut new normal(2)

Di masa pendemi sekarang kebanyakan masyarakat melakukan kebiasaan yang tidak sehat seperti penggunaan rokok tembakau dan rokok elektrik yang membuat tingginya risiko terjangkitnya covid-19 di karenakan covid-19 menyerang system pernapasan manusia(3). Para ahli telah mengindikasikan bahwa perokok dan pengguna rokok elektrik dapat meningkatkan risiko infeksi COVID-19 yang parah dan hasil yang lebih buruk. (4). Perubahan penggunaan rokok elektrik di Amerika sejak pandemi COVID-19 dimulai. Di antara 2125 pengguna pernah merokok, 1198 (56,4\%) melaporkan bahwa mereka mengubah jumlah penggunakan sejak dimulainya pandemi COVID-19 (5). Penggunaan rokok elektrik di kalangan remaja dan dewasa muda telah menjadi perhatian kesehatan masyarakat. Pada tahun 2014, penggunaan rokok elektrik oleh dewasa muda berusia 18-24 tahun saat ini melampaui orang dewasa berusia lebih dari 25 tahun(6).

Menurut Global Youth Tobacco Survey (GYTS) Indonesia merupakan Negara dengan perokok remaja tingkat tertinggi di dunia (7). Dalam laporan RISKESDAS tahun 2018 profil pengguna rokok elektrik di Indonesia usia relative muda (usia 10-14 10,6\%, usia $15-1910,5 \%$, usia $20-$ $247,0 \%$ ) dan berprofesi sebagai pelajar, status pendidikan relative tinggi (perguruan tinggi 4,9\%, SMA 4,0\% SMP 3,3\% SD 1,6\% tidak sekolah 0,8\% ), tinggal di perkotaan (kota 3,8\%, desa 1,6 \%) , prevalensi pengguna rokok elektrik sebanyak 2,8\%, pengguna rokok elektrik laki-laki $(2,8 \%)$ dan perempuan $(2,7 \%)$ relative sama. Lima provinsi pengguna rokok elektrik tertinggi di Indonesia yaitu : Yogyakarta 7,4\%, Kalimantan Timur 6,0\%, Jakarta 5,9\%, Kalimantan Selatan 4,9\% dan Bali
4,2\% (8). Di Indonesia, regulasi terkait peredaran dan penggunaan rokok elektronik belum ada yang mengatur. Badan Pengawas Obat dan Makanan (BPOM) menyatakan rokok elektronik merupakan produk ilegal dan tidak aman. Produk ini belum diuji secara klinis; oleh karena itu berbahaya (9). Kemudahan mengakses memiliki peranan penting dalam pengguna rokok elektrik. Karena harga yang tejangkau, terdapat toko khusus vape atau rokok elektrik yang sudah tersebar serta toko online yang menjual berbagai jenis rokok elektrik membuat pengguna mudah mengakses rokok elektrik (10)

Tujuan penelitian ini untuk untuk menganalisis adanya hubungan antara faktor kemudahan akses produk rokok elektrik dengan perilaku penggunaan rokok elektrik di era new normal pada mahasiswa kesehatan masyarakat UMKT

\section{BAHAN DAN METODE}

Penelitian ini menggunakan jenis Analisis korelasi dengan desain Cross Sectional yang Teknik pengambilan sampel menggunakan teknik Stratified random sampling (11) .Kuesioner dalam penelitian ini berisi pertanyaan terkait karakteristik responden, kemudahan akses dalam memperoleh rokok elektrik dan perlaku penggunaan rokok elektrik di masa new normal. Kuesioner dalam penelitian ini dalam bentuk google form yang sudah di uji valid. Variabel indipenden dalam penelitian ini kemudahan akses peroduk rokok elektrik dikatagorikan jika responden menjawab kuesioner dengan total skor di atas $75 \%$ maka di katagorikan mudah akses dan jika total skor dibawah $75 \%$ maka di katagorikan tidak mudah akses (12). Variable dependen dalam penelitian ini perilaku penggunaan rokok elektrik bertujuan untuk melihat pengguna rokok elektrik selama new normal berlaku dengan kuesioner yang sudah di katagorikan responden pengguna rokok elektrik jika menjawab "Ya" dan bukan pengguna rokok elektrik jika menjawab "Tidak" pada kuesioner yang diberikan (13). 


\section{HASIL DAN PEMBAHASAN}

Berdasarkan hasil penelitian yang dilakukan di dapat hasil sebagai berikut.

Tabel 1. Distribusi Frekuensi Karakteristik Responden

\begin{tabular}{|c|c|c|}
\hline Variabel & $\mathbf{n}$ & $\%$ \\
\hline \multicolumn{3}{|l|}{ Usia } \\
\hline 18 & 18 & 7,8 \\
\hline 19 & 63 & 27,3 \\
\hline 20 & 88 & 38,1 \\
\hline 21 & 49 & 21,2 \\
\hline 22 & 11 & 4,8 \\
\hline 23 & 2 & 0,9 \\
\hline \multicolumn{3}{|c|}{ Jenis Kelamin } \\
\hline Perempuan & 167 & 72,3 \\
\hline Laki-laki & 64 & 27,7 \\
\hline \multicolumn{3}{|l|}{ Semester } \\
\hline Semester 2 & 86 & 37,2 \\
\hline Semester 4 & 75 & 32,5 \\
\hline Semester 6 & 70 & 30,3 \\
\hline Total & 231 & 100 \\
\hline
\end{tabular}

Berdasarkan tabel 1 menunjukan bahwa responden terbanyak berusia 20 tahuna dengan responden sebanyak 88 engan presentase $38,1 \%$ dan dan di lanjutkan responden berusia 19 tahun sebesar $27,3 \%$, responden berusia 21 sebesar $21,2 \%$ responden berusia 18 tahun sebesar $7,8 \%$, responden 22 tahun sebesar $4,8 \%$ dan responden paling sedikit berusia 23 tahun sebesar $0,9 \%$. Jenis Kelamin menunjukan bahwa responden terbanyak berjenis kelamin perempuan sebanyak 167 responden dengan presentase $72,3 \%$ dan responden laki-laki 64 responden dengan presentase $27,7 \%$. Distribusi semester responden menunjukan bahwa responden tertinggi berada di semester 2 dengan 86 responden dengan presentase $37,2 \%$ dan responden terendah berada di semester 6 dengan 70 responden dengan presentase 30,3\%.

Tabel 2. Distribusi Perilaku merokok elektrik dan kemudahan akses

\begin{tabular}{lcc}
\hline \multicolumn{1}{c}{ Variabel } & n & $\%$ \\
\hline $\begin{array}{l}\text { Perilaku Pengguaan } \\
\text { Rokok Elektrik }\end{array}$ & & \\
Ya & 67 & 29,0 \\
Tidak & 164 & 71,0 \\
$\begin{array}{l}\text { Kemudahan Akses } \\
\text { Produk Rokok }\end{array}$ & & \\
Elektrik & & \\
Mudah Diakses & 208 & 90,0 \\
Tidak Mudah Diakses & 23 & 10,0 \\
\hline \multicolumn{1}{c}{ Total } & $\mathbf{2 3 1}$ & $\mathbf{1 0 0 , 0}$ \\
\hline
\end{tabular}

Berdasarkan tabel 2 menunjukan bahwa menunjukan bahwa dari 231 responden terdapat sebanyak 67 responden dengan presentase $29 \%$ pengguna rokok elektrik di era new normal pada mahasiswa kesehatan masyarakat UMKT dan sebanyak 164 responden dengan presentase $71,0 \%$ bukan pengguna rokok elektrik di era new normal pada mahasiswa kesehatan masyarakat UMKT. Tabel 2 juga menunjukan bahwa menunjukan bahwa dari 231 responden terdapat sebanyak 208 responden dengan presentase $90 \%$ yang mudah mengakses produk rokok elektrik dan sebanyak 23 responden dengan presentase $10 \%$ tidak mudah mengakses produk rokok elektrik Penelitian ini juga sejalan dengan teori Lawrance Green yang menyatakan bahwa faktor enabling merupakan tersedia atau tidak tersedianya fasilitas-fasilitas atau sarana-sarana. kemudahkan akses penggunaan rokok elektrik seperti harga yang tejangkau, terdapat toko khusus vape atau rokok elektrik yang sudah tersebar serta toko online yang menjual berbagai jenis rokok elektrik membuat pengguna mudah mengakses rokok elektrik.

Hasil uji analisis menunjukan hasil bahwa 55 responden dengan presentase $82.1 \%$ adalah penggunaan rokok elektrik dan menyatakan produk rokok elektrik mudah diakses, sedangkan sebesar 12 responden dengan presentase 17.9\%. adalah penggunaan rokok elektrik menyatakan produk rokok elektrik tidak mudah akses, sebesar 153 responden dengan presentase 93.3\%, bukan penggunaan rokok elektrik menyatakan produk rokok elektrik mudah akses, sementara 11 responden dengan presentase 6.7\%bukan penggunaan rokok elektrik menyatakan produk rokok elektrik tidak mudah akses. Dan hasil analisis uji chi-square di peroleh nilai $\mathrm{P}=0,010<$ 0,05 yang artinya ada hubungan antara kemudahan akses produk rokok elektrik dengan penggunaan rokok elektrik di era new normal pada mahasiswa kesehatan masyarakat UMKT. Nilai odds ratio (OR) menunjukan hasil sebesar 3,035 yang artinya kemudahan akses produk rokok elektrik mempengaruhi perilaku penggunaan rokok elektrik. Nilai confidence interval (CI) $95 \%$ mendapatkan hasil sebesar 1,266 - 7,274 yang artinya nilai CI diatas 1 sehingga kemudahan akses produk rokok elektrik dengan perilaku 
penggunaan rokok elektrik bersifat faktor risiko. Penelitian ini sejalan dengan penelitian (14) yang menyatakan adanya hubungan antara keterjangkauan membeli rokok elektrik dengan gaya hidup

\section{KESIMPULAN DAN SARAN}

Berdasarkan hasil penelitian dari 231 responden sebanyak 208 responden dengan presentase $90 \%$ menyatakan produk rokok elektrik mudah diakses di era new normal. Dari 231 responden sebanyak 67 responden dengan presentase $29 \%$ pengguna rokok elektrik di era new normal. Dan ada hubungan antara kemudahan akses produk rokok elektrik dengan penggunaan rokok elektrik di era new normal pada mahasiswa kesehatan masyarakat UMKT. Perlu adanya strategi pengendalian penggunaan rokok elektrik dengan menambahkan secara tersurat aturan Kawasan Tanpa Rokok yang sudah ada memasukan didalamnya rokok elektrik .

\section{UCAPAN TERIMAKASIH}

Penulis mengucapkan terima kasih sebesarbesarnya kepada segenap civitas akademika prodi Kesehatan Masyarakat FKM UMKT dan pihak yang terlibat dalam penelitian ini.

\section{DAFTAR PUSTAKA}

1. Wahyu AM, Sa'id M. Produktivitas selama work from home : sebuah analisis psikologi sosial ( productivity during work from home : a social psychological analysis ). J Kependud Indones. 2020;2902(Edisi Khusus Demografi dan Covid-19):53-60.

2. Megahpura FT. Perlindungan Hukum Terhadap Konsumen Atas Hak Informasi Produk Cairan Rokok Elektrik (E-Juice) Di Yogyakarta. UNIVERSITAS ISLAM INDONESIA YOGYAKARTA; 2018.

3. Singh AG, Chaturvedi P. Tobacco use and vaping in the COVID-19 era. Head Neck. 2020;42(6):1240-2.

4. Kelly BC, Pawson M, Vuolo M. Beliefs on COVID-19 Among Electronic Cigarette Users: Behavioral Responses and Implications for COVID Prevention and E-Cigarette Interventions. J Drug Issues. 2020;

5. Gaiha SM, Lempert LK, Halpern-Felsher B. Underage youth and young adult e-cigarette use and access before and during the coronavirus disease 2019 pandemic. JAMA Netw Open. 2020;3(12):1-16.

6. U.S. Department of Health and Human Services. E-Cigarette Use Among Youth and Young Adults: Fact Sheet. Surg Gen Rep. 2016;2.

7. Agina DT, Pertiwi FD, Avianty I. Faktor-Faktor Yang Berhubungan Dengan Perilaku Penggunaan Vapor di Kalangan Siswa Sekolah Menengah Kejuruan Bina Sejahtera 2 Kota Bogor. PROMOTOR. 2019;2(2):101-11.

8. Fauzi R. Epidemi Rokok Elektronik di Indonesia. 2020;

9. Lestari KS, Humairo MV, Agustina U. Formaldehyde Vapor Concentration in Electronic Cigarettes and Health Complaints of Electronic Cigarettes Smokers in Indonesia. Dobaradaran S, editor. J Environ Public Health [Internet]. 2018;2018:9013430. Available from: https://doi.org/10.1155/2018/9013430

10. Sunarti S, Illahi RA, Ishal IT, Dirgandiana M, Diana KN, Mariam S. Hubungan Kemudahan Akses Terhadap Perilaku Penggunaan Rokok Elektrik pada Mahasiswa di Universitas Muhammadiyah Kalimantan Timur. 2020;1(1):9-17.

11. Arieska PK dan NH. Pemilihan Teknik Sampling Berdasarkan Perhitungan Efisiensi Relatif. J Stat. 2018;6(2):166-71.

12. Illahi RA. Hubungan Kemudahan Akses Terhadap Perilaku Penggunaan Rokok Elektrik Pada Mahasiswa Di Universitas Muhammadiyah Kalimantan Timur. Vol. 21, Malaysian Palm Oil Council (MPOC). 2020. 1-9 p.

13. Nasution PA. Hubungan Perilaku Merokok Dan Vaping Terhadap Kejadian Gejala Depresi Pada Pelajar Slta Di Provinsi Jawa Barat Tahun 2017. 2019;

14. Istiqomah D, Cahyo K, Indraswari R. Gaya Hidup Komunitas Rokok Elektrik Semarang Vaper Corner. J Kesehat Masy. 2016;4(2):20312. 